Research paper

\title{
Demography and socioeconomic vulnerability influence fire occurrence in Bariloche (Argentina)
}

\author{
Mariana Dondo Bühler ${ }^{\mathrm{a}, *}$, Mónica de Torres Curth ${ }^{\mathrm{a}, \mathrm{b}, \mathrm{c}}$, Lucas Alejandro Garibaldi ${ }^{\mathrm{a}, \mathrm{d}}$ \\ a Sede Andina, Universidad Nacional de Río Negro (UNRN), Mitre 630, CP 8400 San Carlos de Bariloche, Río Negro, Argentina \\ ${ }^{\mathrm{b}}$ Departamento de Matemática, Centro Regional Universitario Bariloche, Universidad Nacional del Comahue, Quintral 1250, CP 8400 Bariloche, Río Negro, Argentina \\ ' Laboratorio de Ecotono, INIBIOMA-CONICET and CRUB-UNCOMA, Pasaje Gutierrez 1125, CP 8400 Bariloche, Río Negro, Argentina \\ d Consejo Nacional de Investigaciones Científicas y Técnicas (CONICET), Mitre 630, CP 8400 San Carlos de Bariloche, Río Negro, Argentina
}

\section{H I G H L I G H T S}

- Occurrence of vegetation fires increased in the recent years in Bariloche city.

- Fire density increased with population density temporally and spatially in Bariloche.

- Neighborhoods with higher socioeconomic vulnerability had higher fire density.

- Economically disadvantaged residents may have no incentives to protect forests.

- Socioeconomic and biophysical data should be used in urban planning to prevent fires.

\section{A R T I C L E I N F O}

\section{Article history:}

Received 22 August 2011

Received in revised form 11 October 2012

Accepted 12 October 2012

Available online 3 November 2012

\section{Keywords:}

Fire

Patagonia

Population density

Quantile regression

Socioeconomic vulnerability

Wildland-urban interface

\begin{abstract}
A B S T R A C T
Despite the enormous impact of fires on human welfare, few studies evaluated the influence of demographic and socioeconomic conditions on the occurrence of vegetation fires. We used quantile regression to estimate the dependence of fire density (no. ha ${ }^{-1}$ ) on demographic and socioeconomic conditions for neighborhoods with contrasting fire density levels (i.e., quartiles), using data of Bariloche, a city with a large wildland-urban interface zone, as a case study. We evidenced that socioeconomic and demographic variables can explain part of the fire density's variability not explained by biophysical variables, through a principal component analysis, and examined the goodness of fit of the model to the data through the Akaike's Information Criterion. Opposite to that observed in natural areas, fire density increased in the recent years in the interface areas. Population density was positively and significantly related to interface fire density, likely representing the effect of anthropic pressure on the environment. Fire density increased with socioeconomic vulnerability, particularly, high unemployment rate, high level of teenagers that neither study nor work, and low educational levels. Therefore, population welfare and education must be the most important target for public policies, even from a fire preventive viewpoint. The demographic and socioeconomic influence on wildland-urban interface fires should be explicitly considered by policymakers, and complement biophysical data to plan land use and regulate forest management, as well as to measure the additional effort needed for firefighting (e.g., investments in infrastructure and extra workers) to attend the greater population.
\end{abstract}

(C) 2012 Elsevier B.V. All rights reserved.

\section{Introduction}

Fire in the wildlands-urban interface (hereafter interface for brevity) has become a major concern in recent years, particularly where population is growing, and urbanization into bordering lands is accelerating. During the last 300 years, humans expanded

\footnotetext{
* Corresponding author. Tel.: +54 29494506703.

E-mail addresses: mdbuhler@unrn.edu.ar (M. Dondo Bühler), mdetorrescurth@gmail.com (M. de Torres Curth), lgaribaldi@unrn.edu.ar (L.A. Garibaldi).
}

urban settlements and land use into wildlands, and by the year 2000 these anthropogenic biomes reached $37 \%$ of the earth surface free of ice (Ellis, Klein Goldewijk, Siebert, Lightman, \& Ramankutty, 2010). This expansion of the interface zone requires new fire prevention and management practices. In the interface, buildings are contiguous to wild areas prone to fire, and anthropogenic ignitions are believed to be more common than in other areas (PNMF, 2011; Syphard et al., 2007). Research is needed to comprehend causes and circumstances underlying interface fire occurrence and gain a better understanding of the factors that predispose people to ignite fires. This information will be useful for policymakers in improving their resource allocations for prevention and fire management. 
Several studies analyze the influence of biophysical or climate conditions on fire occurrence and magnitude (e.g., Countryman, 1972; Haight, Cleland, Hammer, Radeloff, \& Rupp, 2004; Kitzberger, Veblen, \& Villalba, 1997). Despite the increasing expansion of interface areas, most studies have been carried out in natural areas (e.g., Chou, Minnich, \& Chase, 1993; Mermoz, Kitberger, \& Veblen, 2005; Veblen, Kitzberger, \& Donnegan, 2000), defined here as areas without human settlements (Ellis et al., 2010). Demographic and socioeconomic factors have been studied less, but they may also greatly influence fire break out in natural as well as interface areas (Leone, Lovreglio, \& Martinez-Fernandez, 2002; Macie \& Hermansen, 2002; Martell, Otukol, \& Stocks, 1987; Mercer \& Prestemon, 2005; Padilla \& Vega Garcia, 2011; Syphard et al., 2007).

Among demographic characteristics, population density and age range structure may influence fire patterns in interface zones. For example, the number of ignitions in Florida (Mercer \& Prestemon, 2005) and Upper Midwest in the USA (Cardille, Ventura, \& Turner, 2001) was positively related to the population present in the study area. In contrast, other studies (Guyette, Muzika, \& Dey, 2002; Keeley, 2005; Syphard et al., 2007; Syphard, Radeloff, Hawbaker, \& Stewart, 2009) propose that humans affect fire occurrence both positively and negatively depending on the level of human presence. On one hand, high population and housing density are related to high fire occurrence, since humans ignite fires. However, on the other hand, when population density and urban development are higher than a certain threshold, fire occurrence decrease because vegetation fuels became insufficient and discontinuous (Cardille et al., 2001; Keeley, Fotheringham, \& Morais, 1999). In addition, the fear of being identified as the fire starter could deter people from igniting fires. Additional research is required to establish whether human presence explains fire occurrence through nonlinear models. Regarding age range structure, some studies indicate that elderly and young populations are less careful, thus increasing chance of fire (Jennings, 1997).

Socioeconomic conditions affect people's interactions with their environment (Brocklesby \& Hinshelwood, 2001), for example, educational levels may impact fire occurrence. Fire risk and education campaigns were conducted to increase awareness and reduce hazard behaviors (Collins, 2005), but few studies have quantified the effectiveness of these efforts. Collins (2005) stated that although campaigns increased public knowledge of the biophysical risk of interface fires, they did not influence hazard reduction behaviors. On the contrary, Prestemon, Butry, Abt, and Sutphen (2010) found statistical evidence for reductions in preventable fires occurrence, burned areas, and economic losses. Regarding other socioeconomic descriptors, in Florida, for example, unemployment and occurrence of interface fires were negatively related (Mercer \& Prestemon, 2005; Prestemon \& Butry, 2005). In contrast, a positive association was found in Spain (Martinez, Chuvieco, \& Martín, 2000; Martinez, Vega García, \& Chuvieco, 2009) and it was suggested that economic conflicts, such as unemployment, may stimulate intentional fires as a sign of discontent. Despite being recognized in literature that human factors affect interface fire occurrence, findings in case studies are contradictory (Table 1). Therefore, spatial patterns of interface fires are not well understood (Sturtevand \& Cleland, 2007).

Most of the studies that relate socioeconomic factors to fire occurrence were achieved in developed countries (Table 1), characterized by a higher level of industrialization and quality of life (e.g., low poverty, high levels of education and health, adequate housing conditions). It is unclear if associations found in developed countries between socioeconomic conditions and fire occurrence can be extended to developing countries with contrasting demographic characteristics and greater socioeconomic vulnerability. This latter, is expressed in multiple forms, such as a lack of productive assets and human and social capital to take advantage of existing opportunities (Katzman, Beccaria, Filgueira, Golbert, \& Kessler, 1999).
Socioeconomic vulnerability influences risk and harms exposure and also affects the capacity to recover from hazards (Cohen, 2000; Johnson Gaither et al., 2011).

In Argentina, more than $10 \%$ of the vegetation fires occur in San Carlos de Bariloche (hereafter Bariloche), a city located in Northwestern Patagonia (PNMF, 2011). This city is surrounded by the Nahuel Huapi National Park with an extensive interface zone. Historically, fires have been used as a management tool to convert land for productive purposes, such as to facilitate hunting, to clear land for grazing or to harvest wood (Veblen, Kitzberger, Raffaele, \& Lorenz, 2003). Previous studies in natural ecosystems of the region determined that precipitation deficit and high temperature were associated with burned area, but not with number of ignitions (de Torres Curth, Ghermandi, \& Pfister, 2008; Kitzberger et al., 1997; Kitzberger, 2002). Fires ignitions in natural areas in the region have declined in the last 60 years (Kitzberger \& Veblen, 2003), but it is unclear if urban and interface fires have followed the same trend. In an exploratory study (de Torres Curth, Biscayart, Ghermandi, \& Pfister, 2012), researchers mapped the municipal district based on fire danger categories elaborated by the Fire Prevention Technical Council (BCFS-PNMF, 2002), and on a second map highlighted where fires actually occurred in the neighborhoods. They observed that fires in Bariloche did not occur in places with more vegetation fuel availability or in hillsides with major solar or wind exposure, as predicted by the Fire Prevention Technical Council. On the contrary, fires commonly occurred in neighborhoods located in the southwest of the city, where major socioeconomic vulnerability impacts the most.

In this article, we quantitatively analyzed the links between demographic or socioeconomic conditions and fire occurrence. We compiled a new database, which includes historical fire trends in Bariloche (Fig. 1), as well as demographic and social variables from the Argentinean National Census. Our main goals were: (1) to gain a better understanding of factors that predispose people to start fires (i.e., establishing the link between socioeconomic conditions and human-caused ignitions), (2) to provide a comparison of demographic and socioeconomic influence on fire occurrence between developed and developing countries, and (3) to develop information for policymakers that may improve their understanding of interface fires, leading to greater prevention, and better fire management. This study also contributes to the understanding of spatial variability of interface fires and urban development planning.

\section{Materials and methods}

\subsection{Study area}

Bariloche is located in Northwestern Patagonia and is the most populated city in the region with approximately 115 thousand inhabitants (INDEC, 2010). It is situated within the Nahuel Huapi National Park $\left(41^{\circ} 4^{\prime}-41^{\circ} 1^{\prime}\right.$ South, $71^{\circ} 6^{\prime}-71^{\circ} 1^{\prime}$ West), in the south coast of Nahuel Huapi Lake. Municipal surface covers 22,700 ha and has an extended shape with an approximately $40 \mathrm{~km}$ long of perimeter. The municipal district has an extensive interface area, bordering natural and protected areas. Urban development has historically spread mostly on the plains and hills at altitudes that vary from 760 to $900 \mathrm{~m}$ above sea level (Abalerón, 2001). In the last decades, Bariloche has experienced a strong demographic pressure and intense urban growth (Matossian, 2010). Bariloche's urban landscape has strong socio-spatial inequalities, due to tourism as the main economic activity, a rugged topography, the lack of planning in governmental actions, a widespread urban area with a heterogeneous social composition, migration, and land value rise (Matossian, 2010). Land uses cover mainly urban (residential and commercial), forestry land of exotic conifer, tourism and 
Table 1

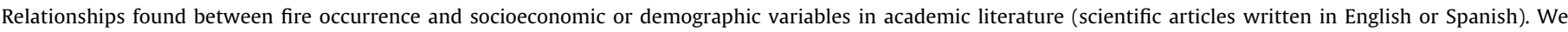

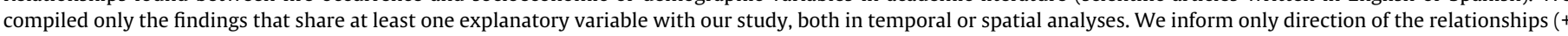
or -), since magnitude is influenced by units of measure, which varied among studies.

\begin{tabular}{|c|c|c|c|c|}
\hline Explanatory variable & Citation & Study area & Dependent variable & Association \\
\hline \multirow[t]{10}{*}{ Population density $(+)^{\mathrm{a}}$} & Prestemon and Butry (2005) & FL, USA & No. of arsons & - \\
\hline & $\begin{array}{l}\text { Vega García, Woodard, Titus, } \\
\text { Adamowicz, and Lee (1995) }\end{array}$ & Whitecourt Forest, Alberta, Canada & Fire occurrence & + \\
\hline & Cardille et al. (2001) & $\begin{array}{l}\text { Upper Midwest, USA (Minnesota, } \\
\text { Wisconsin, MI) }\end{array}$ & Fire occurrence & + \\
\hline & Guyette et al. (2002) & Ozark Highlands in Missouri, USA & $\%$ de sites burned & Non-linear \\
\hline & Leone et al. (2002) & Gargano National Park, Italy & No. of fires & n.a. \\
\hline & Keeley (2005) & San Francisco East Bay, USA & No. of fires & Non-linear \\
\hline & Mercer and Prestemon (2005) & FL, USA & No. of fires & + \\
\hline & Padilla and Vega Garcia (2011) & Spain & Fire occurrence & + and - \\
\hline & Syphard et al. (2007) & CA, USA & No. of fires & Non-linear \\
\hline & Syphard et al. (2009) & $\begin{array}{l}\text { Mediterranean climate ecosystems } \\
\text { (Mediterranean Basin, central } \\
\text { Chile, the Cape Region of South } \\
\text { Africa, southwestern Australia, and } \\
\text { parts of California and northern } \\
\text { Baja California in North America) }\end{array}$ & No. of fires & Non-linear \\
\hline \multirow[t]{4}{*}{ Poverty (n.a.) } & Prestemon and Butry (2005) & FL, USA & No. of arsons & + and n.a. \\
\hline & $\begin{array}{l}\text { Roman-Cuesta, Garcia, and } \\
\text { Retana (2003) }\end{array}$ & Chiapas, Mexico & Fire incidence & - \\
\hline & Butry and Prestemon (2005) & FL, USA & No. of arsons & - and n.a. \\
\hline & Mercer and Prestemon (2005) & FL, USA & No. of fires & - \\
\hline \multirow[t]{2}{*}{ Education $(-)$} & Butry et al. (2002) & FL, USA & No. of fires & - \\
\hline & Prestemon et al. (2010) & FL, USA & $\begin{array}{l}\text { No. of accidentally ignited } \\
\text { human caused-fires }\end{array}$ & - \\
\hline \multirow[t]{7}{*}{ Unemployment (+) } & Prestemon and Butry (2005) & FL, USA & No. of arsons & - \\
\hline & Leone et al. (2002) & Gargano National Park, Italy & No. of fires & + \\
\hline & Butry and Prestemon (2005) & FL, USA & No. of arsons & + and n.a. \\
\hline & Mercer and Prestemon (2005) & FL, USA & No. of fires & - \\
\hline & $\begin{array}{l}\text { Vilar de Hoyo, Gómez Nieto, } \\
\text { Martín Isabel, and Martínez } \\
\text { Vega (1997) }\end{array}$ & Madrid and Huelva, Spain & No. of human ignited fires & + \\
\hline & Martinez et al. (2000) & Spain & Fire occurrence & + \\
\hline & Martinez et al. (2009) & Spain & No. of fires/forest area & + \\
\hline Ownership (+) & Cardille et al. (2001) & $\begin{array}{l}\text { Upper Midwest, USA (Minnesota, } \\
\text { Wisconsin, MI) }\end{array}$ & Fire occurrence & Opposite signs \\
\hline
\end{tabular}

n.a., no association was found.

Non-linear, the relationship was positive or negative, depending on the level of human presence.

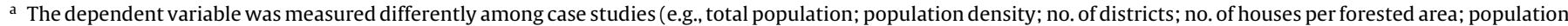
density per area protected).

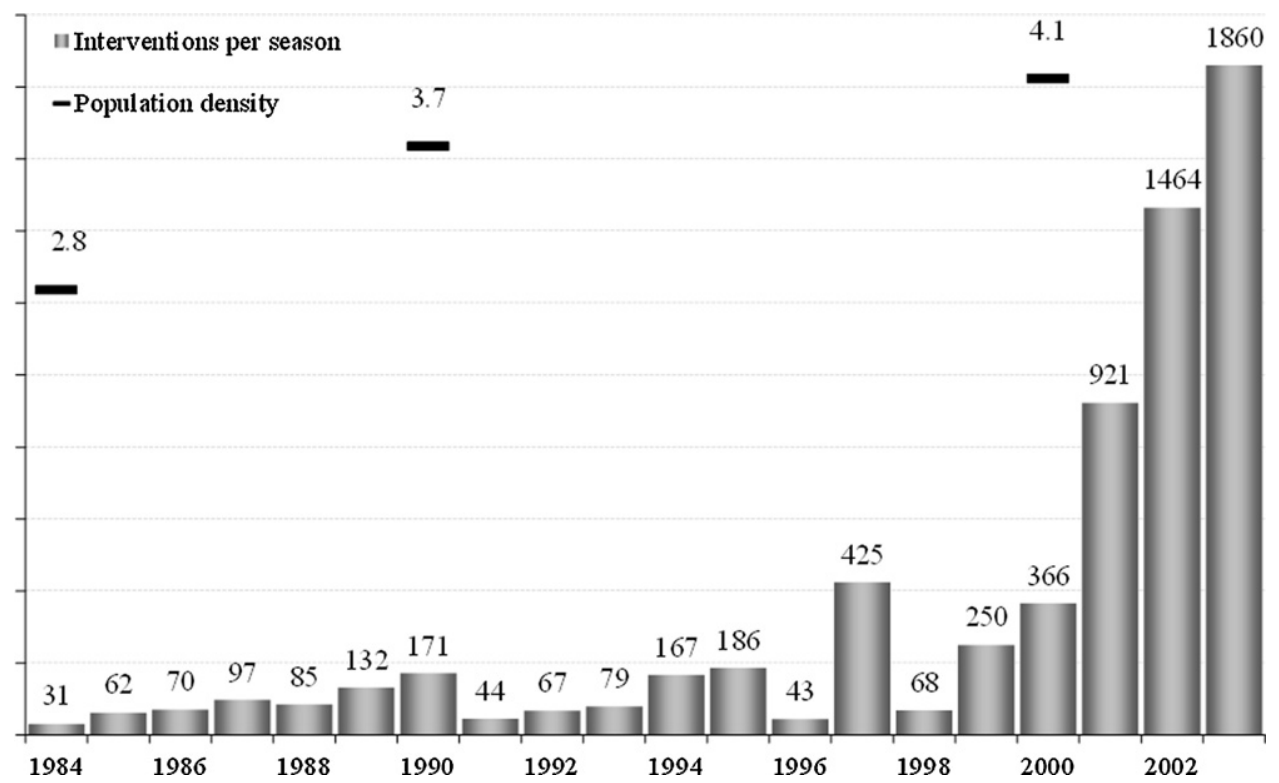

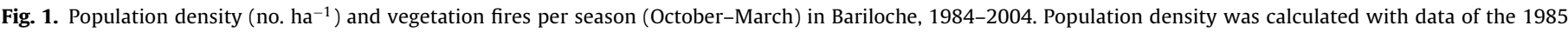
Provincial Census and 1991 and 2001 National Censuses. The municipal district area increased in 2000 and population growth increased more than proportionally. 
recreational activities (mostly in the west part of the city) (Mermoz et al., 2009).

Fire season in Bariloche extends from October to March coinciding with the period of higher temperatures and water deficit (Kitzberger \& Veblen, 2003), and the consequent accumulation of dry vegetal fuel. Fire management in Bariloche depends on three government organizations since the different areas of the interface zone are jurisdictions of the National Park Administration, Río Negro province, or Bariloche Township. These organizations establish their firefighting strategies using the interface fire danger index elaborated by the Fire Prevention Technical Council, based on type and availability of fuels, topography, water availability, accessibility, land use, and degree of urbanization, without considering demographic and socioeconomic conditions.

\subsection{Data}

The response variable was the density of interface fires by neighborhood, defined as the ratio between vegetation ignition average numbers that occurred during the 2002-2005 fire seasons in urban and suburban Bariloche, and the neighborhood areas (thus expressed as no. fires ha- ${ }^{-1}$ ). Fires included were those initiated in the vegetation and not the ones initiated in the structures or as forest debris burnings. These data were registered by the firefighting organization at the moment of their interventions (Servicio de Prevención y Lucha contra incendios forestales - SPLIF, unpublished data). We also gathered historical fire data from SPLIF (unpublished data). Although there is no information of causes for each ignition in Bariloche, previous studies determined that in the Patagonia Region human induced fires accounted for $97 \%$ of total ignitions (PNMF, 2011), and that probability of lightning ignited fires during summers with average or below average temperature were almost null (Kitzberger \& Veblen, 2003). Therefore, it was assumed in our study that no ignitions were caused by lightning, and neither could we distinguish between accidental or negligent fires and arson. In the future, we expect that causes of fires will be recorded and further studies will be able to make this distinction.

All of Bariloche's neighborhoods were included in the study. Neighborhoods are territorial subdivisions of municipal districts, originated mainly in administrative decisions (e.g., governmental housing plans), in historical settlements (e.g., of immigrants), or in real estate developments (e.g., subdivisions in suburban zones) (Matossian, 2010). Neighborhoods were chosen as the spatial unit of analysis since many management actions are taken at this level of organization, and they account for the minimum disaggregation level for census and fire data. As neighborhoods have a wide range of area sizes (between a minimum of 1.74 ha and a maximum of $1055 \mathrm{ha}$ ), we used density to reduce the bias of comparing absolute number of fires (Martinez et al., 2009).

Explanatory variables were descriptors of human presence and socioeconomic and demographic conditions, which are considered proxies for the factors (behavioral links) that predispose people to start fires (see Table 2 for variable descriptions and expected relationship to fire density). In addition to the theoretical criteria described in Table 2, these variables were selected because they are available and accessible for technical experts from firefighting agencies. Variables were calculated by neighborhoods as a unit of analysis and obtained from the 2001 National Census (DGEyC, 2005). Historical data of population density were obtained from the General Administration of Statistics and Census of Río Negro province, and the area's historical data of the Municipal district were obtained from Abalerón (2001). Finally, information regarding land rent was not obtainable, but it would be interesting to asses if there are higher incentives to ignite fires when less land is available to develop real estate businesses.
Biophysical factors known to influence fire were also measured (Padilla \& Vega Garcia, 2011). Elevation, slope, and orientation of the slope were taken from the centroid of each neighborhood and considered in the analysis. We also used a variable that synthesizes the vegetal fuel availability and urbanization degree in each neighborhood, which was elaborated by researchers (de Torres Curth et al., 2012) based on an existing vegetation map (Naumann \& Sacholuz, 2000) and on Google ${ }^{\circledR}$ Earth images. Latitude and longitude of each neighborhood were obtained and considered in the models (see below).

\subsection{Statistical analyses}

To fulfill our objectives (1) and (3) we analyzed the relationships between fire density and socioeconomic and demographic determinants. To avoid model misspecifications and omitted variable bias, we tested if socioeconomic variables can explain part of the fire density variability that cannot be explained by biophysical variables using principal component analyses (PCA) and quantile regression ( $Q R$, see below). Two PCA were performed to study the co-variation among explanatory variables in neighborhoods of Bariloche using: (i) biophysical variables or (ii) socioeconomic and demographic variables. PCA is a dimension reduction technique that transforms a data set into a few orthogonal dimensions (principal components), which explains the maximum possible data variability (Jolliffe, 2002), and is especially useful when analyzing correlated variables in regression models (Rangel, Felizola DinizFilho, \& Bini, 2006). With the resulting PCA, we estimated and compared two QR models for the median of fire density as a function of: (a) PCA axes 1 and 2 of the biophysical data as explanatory variables; (b) PCA axes 1 and 2 of the biophysical data and PCA axes 1 and 2 of the socioeconomic data as explanatory variables. If socioeconomic and demographic variables explain fire density's variability not explained by biophysical factors, we would expect a lower Akaike's Information Criterion (AIC) for the model (b) contrasted to model (a). The AIC compares and ranks competing hypothesis (models) in relation to two components: (1) the relative fit to the observed data (through maximum likelihood scores) and (2) the complexity of the model (number of model parameters) (Johnson \& Omland, 2004). The lower the AIC value the more parsimonious the model. Next, we performed an AIC stepwise regression for the median of fire density using the complete set of biophysical and socioeconomic variables through QR analysis (see below). Among the models with the lowest AIC but with similar explanatory power, i.e., $\triangle \mathrm{AIC}<4$ (Burnham, Anderson, \& Huyvaert, 2011; Richards, 2005), we retained the one with more variables, to avoid omitted variable bias. Afterwards, we measured the spatial autocorrelation through the Moran's I coefficient on the residuals of the model (b) and of the multiple QR model to test for the violation of the independent assumption (Moran I function, Ape package, $R$ software; Paradis, Claude, \& Strimmer, 2004). We used a spatial weights matrix in which diagonal entries are zero and off-diagonal entries are $1 /$ (distance between point $i$ and $j$ ) (Paradis et al., 2004). The scores for pairs of points that are closer in space are higher than the more distant points. If there is an effect of space (e.g., close observations are more similar than those far apart), the standard errors, significance tests, and parameter estimation would be biased (Rangel et al., 2006).

Thereafter, we estimated the rate of change in fire density with each demographic or socioeconomic variable through separate $Q R$ for each variable. Strong relationships between fire density and demographic and socioeconomic indicators were expected, because these variables are proxies of anthropic pressure on the environment and human behavior (Table 2). QR allows evaluating whether the strength of these associations varies among neighborhoods with contrasting fire density levels (i.e., quantiles). We 
Table 2

Socioeconomic and demographic explanatory variables used in this study and their hypothesized influence on fire density.

\begin{tabular}{|c|c|c|}
\hline Type and name & Description & Hypothesized influence on fire density \\
\hline \multicolumn{3}{|l|}{ Demography } \\
\hline Population density & Number of inhabitants per ha & $\begin{array}{l}\text { Population density affects fire occurrence both } \\
\text { positively and negatively, depending on the level of } \\
\text { human presence on the territory. }\end{array}$ \\
\hline Age & Percentage of population younger than 17 or older than 65 & $\begin{array}{l}\text { Elderly and young population is less careful with daily } \\
\text { routines, increasing chance of accidental fire. }\end{array}$ \\
\hline \multicolumn{3}{|c|}{ Socioeconomic vulnerability } \\
\hline Educational level & $\begin{array}{l}\text { Percentage of adults (over 17) who have finished high } \\
\text { school }\end{array}$ & $\begin{array}{l}\text { Higher educational levels promote the valuation of } \\
\text { natural resources and their protection, reducing fire } \\
\text { occurrence. }\end{array}$ \\
\hline Unemployment & Percentage of labor force unemployed & $\begin{array}{l}\text { Economic problems stimulate conflicts that can be } \\
\text { manifested by intentional fires. }\end{array}$ \\
\hline Unoccupied teenagers & $\begin{array}{l}\text { Percentage of population from } 15 \text { to } 18 \text { years old that do } \\
\text { not study or work }\end{array}$ & $\begin{array}{l}\text { Boredom can be manifested through arson and } \\
\text { children feel attraction when watching helicopters and } \\
\text { firemen at work. }\end{array}$ \\
\hline Poverty & $\begin{array}{l}\text { Percentage of households that do not achieve minimum } \\
\text { housing conditions and minimum income to acquire basic } \\
\text { goods and services }\end{array}$ & $\begin{array}{l}\text { Lack of resources restricts the possibility to reduce } \\
\text { natural flammability of the surrounding areas and to } \\
\text { build structures with appropriate fireproof materials. }\end{array}$ \\
\hline \multicolumn{3}{|c|}{ o } \\
\hline Ownership & $\begin{array}{l}\text { Percentage of households that own the housing or plot of } \\
\text { land }\end{array}$ & $\begin{array}{l}\text { House-owners reduce probability of ignition, since } \\
\text { they maintain in safer conditions their buildings and } \\
\text { surroundings. }\end{array}$ \\
\hline Natural gas availability & $\begin{array}{l}\text { Percentage of houses where natural gas pipeline } \\
\text { connection or cylinder is available for cooking or heating }\end{array}$ & $\begin{array}{l}\text { Dependence on vegetal fuel promotes interest on } \\
\text { protecting nearby forests and preventing fires. }\end{array}$ \\
\hline
\end{tabular}

performed regressions for each of the three quartiles, which are values that divide the distribution of the data set (i.e., fire density) into four sections with equal quantity of repetitions (i.e., neighborhoods). QR was chosen because the data have heterogeneous variances and are not normally distributed. In addition, QR does not assume any residual distribution, thus it is not biased by outliers or heterogeneous variation in the residuals (Cade \& Richards, 2005). Also, explanatory variables could be associated with fire density only in some sections of the fire density distribution. In those cases, the QR slope will be different for contrasting quantiles and it would not be sufficient to analyze the median or the mean (as other methods do). Slopes for each model and their significance were estimated using the rq function, Quantreg package, R software (Koenker, 2011). Considering findings in previous case studies (Table 1 ), we estimated a non-linear model including a quadratic term of population density and evaluated it with the AIC. In addition, we estimated Spearman correlation coefficients to compare the overall degree of associations with fire density among different socioeconomic and demographic descriptors. Finally, we made a bi-plot graph based on demographic and socioeconomic data, representing observations as points and variables as axes, and enabling an easy analysis of the correlations among variables.

To accomplish our objective (2), we compiled findings from previous studies published in scientific journals (written in Spanish or English) that shared at least one demographic or socioeconomic variable with our study in Table 1 . This table enables the comparison of previous findings and results between developed and developing countries. Magnitude of the slopes could not be compared, since they are influenced by units of measure, which varied among studies and they are not always informed as well.

\section{Results}

Fires increased from less than 50 per season to more than 1800 per season (5900\%) between 1984 and 2004 (Fig. 1). At the same time, population density in the study area increased from 2.8 inhabitants ha ${ }^{-1}$ in 1984 to more than 4 inhabitants ha ${ }^{-1}$ in 2001(48\%; Fig. 1), although the municipal district area increased during that period (3\%). Population density in 2001 varied among neighborhoods from 0.5 to 190 inhabitants ha ${ }^{-1}$.

Table 3

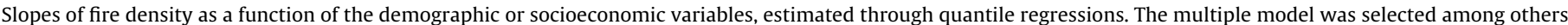
using the AIC. In the simple models, slopes were steeper in neighborhoods with high fire density (75 quantile).

\begin{tabular}{|c|c|c|c|c|}
\hline Variable/quantile & Multiple model (50) & 25 & 50 & 75 \\
\hline \multicolumn{5}{|l|}{ Demography } \\
\hline Population density & 0.001 & $0.001^{*}$ & $0.005^{* *}$ & 0.007 \\
\hline Age & 2.296 & 0.044 & $3.613^{* *}$ & $8.139^{*}$ \\
\hline \multicolumn{5}{|c|}{ Socioeconomic vulnerability } \\
\hline Educational level & - & -0.002 & $-0.008^{* * *}$ & $-0.018^{* *}$ \\
\hline Unemployment & 0.433 & 0.338 & $1.404^{* * *}$ & $3.231^{*}$ \\
\hline Unoccupied teenagers & - & 0.103 & $2.032^{* *}$ & $5.372^{*}$ \\
\hline Poverty & -1.949 & 0.161 & 0.878 & 3.078 \\
\hline \multicolumn{5}{|l|}{ other } \\
\hline Ownership & 0.212 & 0.156 & $1.258^{* * *}$ & 2.440 \\
\hline Natural gas availability & -1.605 & -0.032 & -2.004 & $3.295^{*}$ \\
\hline \multicolumn{5}{|l|}{ Biophysical } \\
\hline Aspect & 0.0004 & & & \\
\hline Slope & -0.005 & & & \\
\hline Latitude & -6.559 & & & \\
\hline
\end{tabular}

\footnotetext{
${ }^{*} P<0.05$.

${ }^{* *} P<0.01$.

${ }^{* * *} P<0.001$
} 


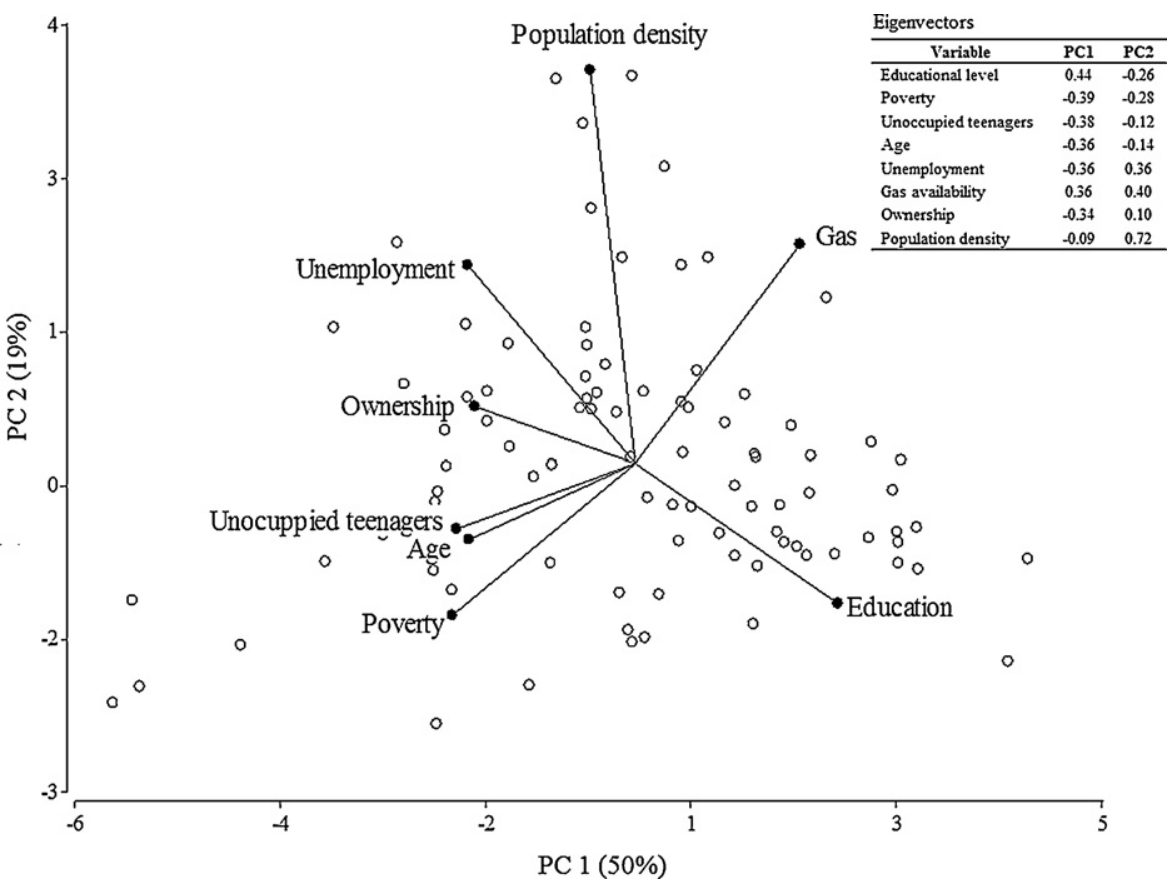

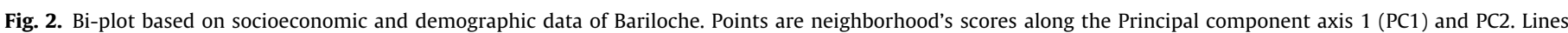

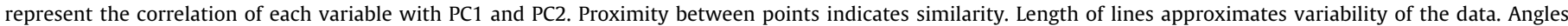

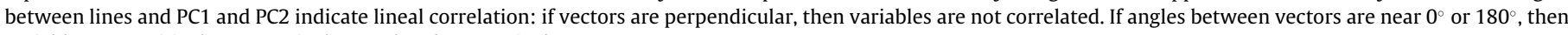
variables are positively or negatively correlated, respectively.

The regression models with the PCA axes as explanatory variables revealed that socioeconomic and demographic characteristics explain part of the fire density's variability that biophysical data cannot explain, since the AIC was greater in the model (a) including only biophysical variables (AIC $=172$ ), than in the model (b) including socioeconomic, demographic, and biophysical variables (AIC=160). The multiple QR model with the best fit to the data according to the AIC showed also the significance of both types of variables to explain fire density differences among neighborhoods (Table 3). The Moran's I coefficient was not significant at the 5\% in neither of the models, indicating absence of spatial correlation among the residuals.

The bi-plot (Fig. 2) shows that socioeconomic explanatory variables can be synthesized into two dimensions or principal components that explain $69 \%$ of their variability among neighborhoods. The first component (PC1) is formed by all variables reflecting socioeconomic vulnerability, such as educational levels, unemployment, unoccupied teenagers, and poverty; and the second component (PC2) is formed mainly by population density. Poverty was highly and negatively correlated to gas availability (Spearman's $r=-0.83$ ) and educational levels $(r=-0.63)$. Educational levels were also strongly associated with unemployment $(r=-0.76)$, teenagers who do not study or work $(r=-0.67)$, and ownership $(r=-0.64)$. Population density was positively correlated to unemployment $(r=0.44)$ and negatively related to educational levels $(r=-0.45)$.

Regarding to the socioeconomic and demographic variables (with the exception of poverty), all the analyses conducted (Spearman correlations, multiple and simple QR models and PCA) lead to the same signs (positive or negative) of the relationships to fire density, further indicating the absence of omitted variable bias. Quantile regression showed that the median of fire density decreases when PC1 increases and socioeconomic vulnerability lowers (slope $=-0.08 ; P$-value $<0.05$ ); and fire density increases when PC2 and population density rises (slope $=0.11 ; P$ value $<0.01$ ). With the exception of poverty, all the socioeconomic or demographic variables significantly explained differences in fire density across neighborhoods in Bariloche in at least one of the quartiles (Table 3). The associations between fire density and any of the socioeconomic or demographic variables were always greater

\section{Population density}

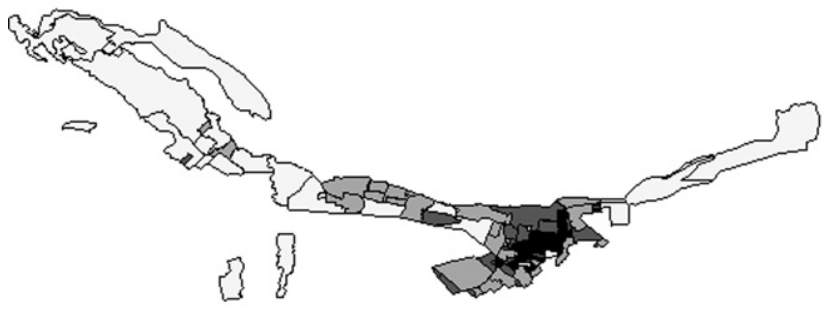

Fire density

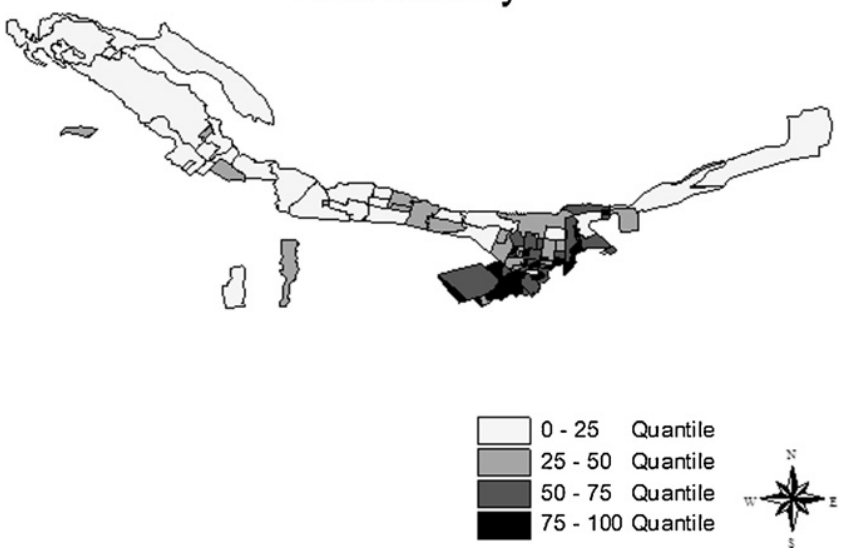

Fig. 3. Fire density (no. ha ${ }^{-1}$ ) per season (average 2002-2005) and population density (2001), by neighborhood. Solid lines are neighborhoods boundaries. 


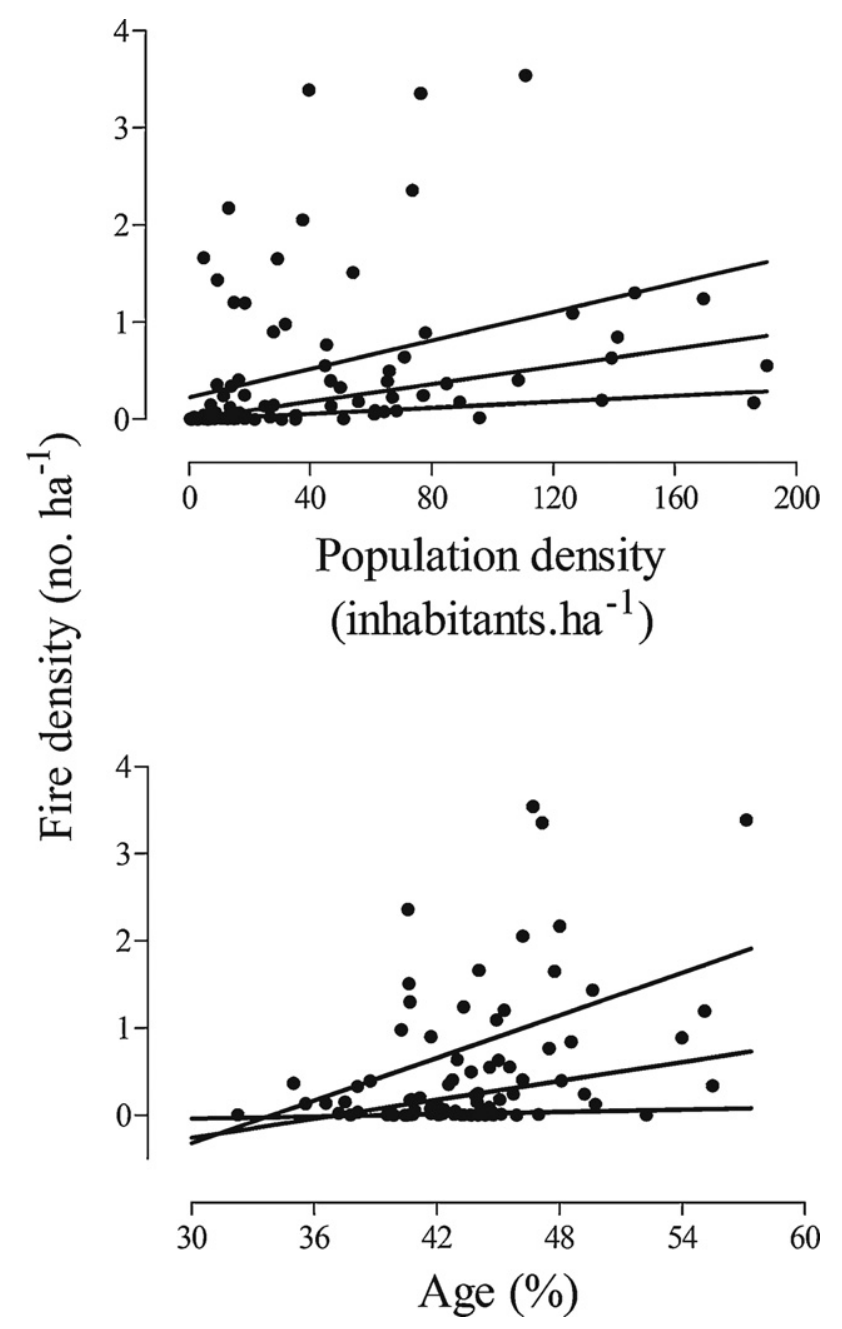

Fig. 4. QR between fire density and demographic descriptors, by neighborhood Solid lines are estimated QR for 25,50 , or 75 quantiles.

for higher quartiles (i.e., neighborhoods with higher fire density), as reflected by higher absolute magnitude of the slopes (Table 3 ). Spearman correlation coefficients showed that among all explanatory variables, population density and educational levels had the highest association with fire density ( 0.57 and -0.55 , respectively), while gas availability showed the smallest Spearman's $r(-0.05)$ with fire density. Fire density increased with population density (Figs. 3 and 4 and Table 3 ) and with the percentage of population younger than 17 or older than 65 years old (Fig. 4 and Table 3). A non-linear model between fire density and population density was estimated, but the coefficient of the quadratic term was not significant $(P>0.05)$, and the AIC was greater than in the simple model. Regarding socioeconomic vulnerability variables, fire density decreased with educational levels, increased with unemployment and the level of unoccupied teenagers, and did not register associations with poverty rates (Fig. 5 and Table 3). Finally, fire density increased with the percentage of owned houses and decreased with gas availability (Table 3 ). The regression models allow projecting the incidence of the variation of socioeconomic and demographic variables on fire density. For example, the model predicts that if the unemployment diminishes by $1 \%$, the median fire density would decrease by 1.4 fires ha ${ }^{-1}$; and if the population density increases by $1 \%$, the median fire density will increase by 0.005 fires ha ${ }^{-1}$.
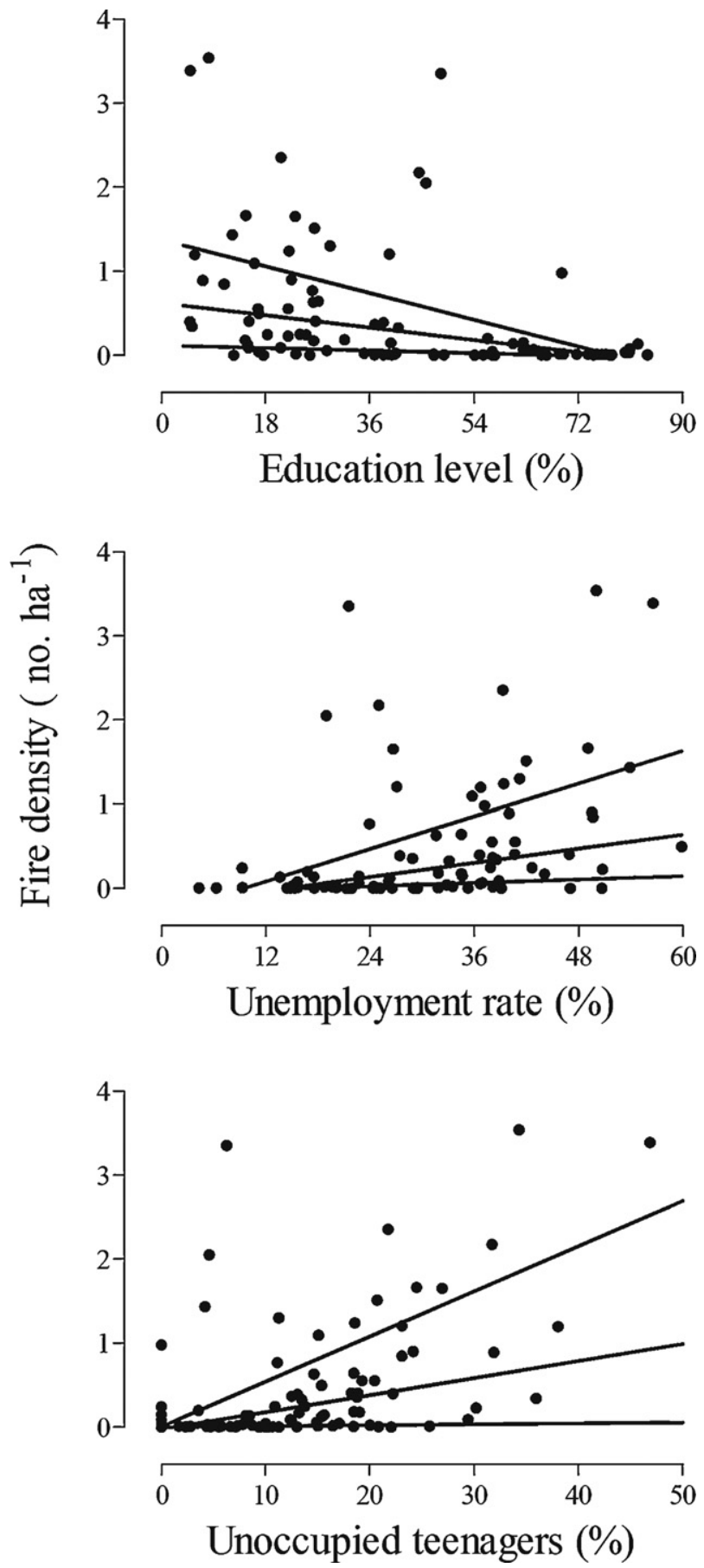

Fig. 5. QR between fire density and socioeconomic vulnerability descriptors of each neighborhood. Solid lines are estimated $Q R$ for 25,50 , or 75 quantiles.

\section{Discussion and conclusions}

Anthropogenic landscapes are dominating the biosphere; however, little is known about the spatial variation of fires within urban areas and factors that predispose humans to ignite fires. In this study, the spatial co-variation of fire density with descriptors of human activity and socioeconomic conditions was quantified to gain a better understanding of these influences. In contrast to the decreasing occurrence of fires in natural areas during the last 60 years near Bariloche (Kitzberger \& Veblen, 2003), interface fires increased from 1984 to 2004 . Our results suggest that human presence and socioeconomic vulnerability promote fire occurrence in 
Bariloche. This influence was higher in neighborhoods where fires were more common, as reflected by greater slopes for higher quartiles for all explanatory variables. Not only environmental but also socioeconomic variables should be considered in risk analysis and mapping of prevention and management strategies.

Fire density increased with population density both historically (in time) and among neighborhoods (in space) in Bariloche. It has been proposed that population density has two opposite effects on fire behavior. On one hand, high population density implies human presence and anthropogenic pressure, increasing chances of occurrence of human fire ignition (Cardille et al., 2001; Keeley et al., 1999; Mercer \& Prestemon, 2005). Nevertheless, after a certain threshold, high population density diminishes the availability of fuel, thereby inhibiting fire spread (Guyette et al., 2002) and increasing the local availability of firefighting resources and effectiveness of fire prevention (Syphard et al., 2007). Thus, it has been suggested that fire density varies non-linearly in response to human influence (Keeley, 2005; Syphard et al., 2007, 2009). Our results indicate a positive relationship between fire density and population density but no thresholds, negative or non-linear association between variables were found. The latter cannot be explained by the greater population density found in other studies, since in Bariloche population density was 4 inhabitants ha ${ }^{-1}$ in average (varying between 0.5 and 190 inhabitants $\mathrm{ha}^{-1}$ ). This was greater than the threshold of 0.4 inhabitants ha ${ }^{-1}$ found in California (Syphard et al., 2007) and of 0.0064 found in Ozark Highlands in Missouri, USA (Guyette et al., 2002). In developed countries, high population density is related to the development and increase of resources available for prevention strategies (Syphard et al., 2007). In contrast, population density in Bariloche is associated with socioeconomic vulnerability, reflected for example by the negative Spearman's $r$ between population density and educational levels (see also Fig. 2). These results suggest that the association between population and fire density varies with socioeconomic differences (e.g., between developing and developed countries) and also could explain heterogeneity in previous findings (Table 1 ).

After population density, the educational level was the variable with the highest Spearman's correlation with fire density, and was strongly negatively associated with unemployment (Fig. 2). Educational level was negatively associated with fire density, as previous studies found in Florida (Butry, Pye, \& Prestemon, 2002; Prestemon et al., 2010). Probably, the population with a higher level of education has a better access to information about prevention, and knowledge of environmental care and natural resources conservation. Therefore, more educated people may be more aware of fire risks, develop safer habits, and behave more carefully. Unemployment rate, on the other hand, was positively related to fire density. The same relationship was found in Spain and it was justified arguing that fire generates the opportunity of a job for firefighters (Martinez et al., 2000, 2009). Nevertheless, in Bariloche we associate this relation with the social conflict that unemployment could generate and the expression of dissatisfaction through arson (de Torres Curth et al., 2012). On the other hand, studies developed in Florida found that lower unemployment was related to higher fire occurrence (Mercer \& Prestemon, 2005; Prestemon \& Butry, 2005). In these studies unemployment rate served as a proxy variable for economic activity at a larger scale than neighborhood. Human pressure on the environment should be higher and thus more fire ignitions should occur in places with high economic activity and low unemployment rate. These results give support to the public resources and efforts allocation to education and employment opportunities generation that may decrease fire occurrence.

Other demographic and socioeconomic descriptors also varied significantly with fire density. Particularly, percentage of young or older population was positively associated with fire density, suggesting that this population group is less careful with daily routines increasing chances of accidental fires (Jennings, 1997) or displeasure being manifested through arson (de Torres Curth et al., 2012). Similarly, our results agree with studies showing that fire occurrence increases in proportion to young populations not attending school nor working. This relationship has been justified proposing that unoccupied teenagers feel boredom and are attracted to watch helicopters and firemen suppressing fires (de Torres Curth et al., 2012; Porrero Rodríguez, 2001). Finally, percentage of poor households was surprisingly not associated with fire density. We expected a significant relationship, as the one found in other dimensions of economic disadvantage. This could be explained by methodological problems, related to the greater error in the measure of this variable. Although we used the poverty data available, it is not so accurately measured in the National Census as the other variables. Poverty data is frequently used from another survey (Permanent Households Survey - EPH), but Bariloche is not included in its sample.

Contrary to that expected, gas availability, a variable which measures the direct population's dependence on forests, was negatively associated with fire density. Many houses in poor neighborhoods in Bariloche that do not have gas pipeline connection or cylinder availability depend on firewood for domestic purposes such as cooking and heating. Thus, we expected that higher dependence on vegetal fuel should promote interest on protecting nearby forests and preventing fires (FAO, 2003). Nevertheless, gas availability was weakly and negatively associated with fire density. Our results support the proposal that people ignite forests intentionally to harvest wood afterwards (de Torres Curth et al., 2012), since the present law in Bariloche allows only to take dry and fallen wood from forests. On the other hand, the percentage of owned houses was positively associated with fire density, which is also contrary to that expected. Previous research found that house-owners reduce probability of ignition because they are more careful in their daily habits and maintain their buildings and their surroundings in safer conditions (Collins, 2005; Jennings, 1997). However, our results can be explained because neighborhoods with the highest level of ownership contain also high numbers of governmental housing plans. These plans consist of low-cost housing and long term financed construction for economically disadvantaged residents. Ownership was positively correlated to unemployment and negatively correlated to educational levels (Fig. 2), which may be stronger drivers of fire density as reflected from higher Spearman's $r$ than that observed between ownership and fire density.

In Bariloche, fires are partly caused by human presence as well as socioeconomic vulnerability. Although population density implies lower vegetal fuel availability, our findings indicate that the more population in an area, the higher the fire density. Additionally, fires are more likely to occur in neighborhoods with a greater density of economically disadvantaged residents. Understanding the causes of fire occurrence has important implications for human welfare and public policy, as reflected by our following conclusions. First, fire occurrence is linked to socioeconomic vulnerability and therefore, population welfare must be the most important target for public policy, even from a fire prevention viewpoint. Bariloche is a touristic city embedded in a National Park and its attractions are related to natural resources, such as forests. However, benefits of tourism are not equally distributed among the population, as reflected by the existence of neighborhoods with high socioeconomic vulnerability. Moreover, management of natural resources is centralized in government organizations without community participation. In this situation, there are no incentives for economically disadvantaged residents to protect and care natural resources (FAO, 2003). Recommendations to reduce number of fires include improving the population's quality of life (e.g., employment opportunities, education), better integration of all residents in the socioeconomic development of the city, and involving 
the local population in natural resource management. Politicians should also be aware of benefits derived from conservation of natural resources. Second, our study provides possible behavioral links between socioeconomic and demographic conditions and fire occurrence, but further information is needed to rigorously support them. Technical experts of firefighting agencies should develop a record of fire events, including accurate data of ignition point and area burned, as well as fire causes. Third, the spatial distribution of fires described here and circumstances that make certain areas more prone to fires should be useful to plan, design and manage the landscape and urban area. Bariloche's population is growing fast and human settlements are occurring within the interface area. Policy makers can use the information provided by this study to plan land use and regulate forest transformation or conservation, as well as to measure the additional efforts needed for firefighting (e.g., investments in infrastructure and extra workers) to attend the greater population.

\section{Acknowledgements}

Financial support was provided by Universidad NacionaldelComahue (Project 04-B156). Servicio de prevención y lucha contra incendios forestales (SPLIF) and General Administrationof Statistics and Census of Río Negro province provided the data set used in this study. We would like to thank four anonymous reviewers and $\mathrm{N}$. Rodriguez Grondona for their thoughtful comments, which guided us to improve the manuscript considerably, and to J. Gowda.

\section{References}

Abalerón, C. A. (2001). The pros and cons of peri-urban management in a tourist city. In Paper produced for the conference rural - Urban encounters: Managing the environment of the peri-urban interface 9-10 November.. Development planning Unit, University College London. http://www.bartlett.ucl.ac.uk/dpu

British Columbia Forestal Service \& Plan Nacional de Manejo del Fuego (BCFSPNMF). (2002). Guía para la prevención de incendios de interfase. República Argentina (Guide for the prevention of interface fires in Argentina). Available in http://www.ambiente.gov.ar/default.asp?IdArticulo=2488 (in Spanish)

Brocklesby, M. A., \& Hinshelwood, E. (2001). Poverty and the environment: What the poor say. An assessment of poverty-environment linkages in participatory poverty assessments. UK: Centre for Development Studies, University of Wales Swansea.

Butry, D. T., \& Prestemon, J. P. (2005). Spatio-Temporal Wildland Arson Crime Functions. American Agricultural Economics Association Annual Meeting, Providence, Rhode Island.

Butry, D., Pye, J., \& Prestemon, J. (2002). Prescribed fire in the interface: Separating the people from the trees. In K. W. Outcalt (Ed.), Proceedings of the eleventh biennial southern silvicultural research conference. General Technical Report SRS48 (pp. 132-136). Asheville, NC, US: Department of Agriculture, Forest Service, Southern Research Station.

Burnham, K., Anderson, D., \& Huyvaert, K. (2011). AIC model selection and multimodel inference in behavioral ecology: Some background, observations, and comparisons. Behavioral Ecology and Sociobiology, 65, 23-35.

Cade, B. S., \& Richards, J. D. (2005). User manual for blossom statistical software. U.S. Geological Survey Open-File Report 2005-1353. 124 pp. http:// www.fort.usgs.gov/products/publications/pub_abstract.asp?PubID $=21536$

Cardille, J. A., Ventura, S. J., \& Turner, M. G. (2001). Environmental and social factors influencing wildfires in the upper Midwest, United States. Ecological Applications, 11, 111-127.

Chou, Y. H., Minnich, R. A., \& Chase, R. A. (1993). Mapping probability of fire occurrence in San Jacinto Mountains, California, USA. Environmental Management, 17, $129-140$.

Collins, T. W. (2005). Households, forests, and fire hazard vulnerability in the American West: A case study of a California community. Environmental Hazards, 6, 23-37.

Countryman, C. M. (1972). The fire environment concept. Berkeley, CA, USA: USDA Forest Service, Pacific Southwest Range and Experiment Station., $12 \mathrm{pp}$.

Cohen, J. D. (2000). Preventing disaster: Home ignitability in the wildland-urban interface. Journal of Forestry, 98, 15-21.

de Torres Curth, M., Biscayart, C., Ghermandi, L., \& Pfister, G. (2012). Wildland urban interface fires and socioeconomic conditions: A case study of a Northwestern Patagonia city. Environmental Management, 49, 876-891.

de Torres Curth, M. I., Ghermandi, L., \& Pfister, G. (2008). Los incendios en el noroeste de la Patagonia: su relación con las condiciones meteorológicas y la presión antrópica a lo largo de 20 años [Fires in northwestern Patagonia: Their relationship with meteorological conditions and anthropic pressure over a 20 years period]. Ecología Austral, 18, 153-167 (in Spanish).
Dirección General de Estadísticas y Censos (DGEyC). (2005). Censo Nacional de Población, Hogares y Viviendas 2001 (National Census of Population and Housing). Argentina: Secretaría de Planificación y Control de Gestión. Provincia de Río Negro. www.rionegro.gov.ar. Accessed online (in Spanish)

Ellis, E. C., Klein Goldewijk, K., Siebert, S., Lightman, D., \& Ramankutty, N. (2010). Anthropogenic transformation of the biomes, 1700 to 2000. Global Ecology and Biogeography, 19, 589-606.

FAO. (2003). Community-based fire management: Case studies from China, The Gambia, Honduras, India, the Lao People's Democratic Republic and Turkey. Rap publication 2003/08. Forest Resources Development Service, Working paper FFM/2. Bangkok, Thailand, FAO Regional Office for Asia and the Pacific.

Guyette, R. P., Muzika, R. M., \& Dey, D. C. (2002). Dynamics of an anthropogenic fire regime. Ecosystems, 5, 472-486.

Haight, R. G., Cleland, D. T., Hammer, R. B., Radeloff, V. C., \& Rupp, T. S. (2004). Assessing fire risk in the wildland-urban interface. Journal of Forestry, 104, 41-48.

Instituto Nacional de Estadística y Censos (INDEC). National Census 2010, preliminary results. www.indec.mecon.gov.ar. Accessed online March 2011.

Jennings. (1997). Socioeconomic factors and the incidence of fire. Federal Emergency Management Agency, United States Fire Administration, National Fire Data Center. http://www.usfa.fema.gov/downloads/pdf/statistics/socio.pdf

Johnson, J. B., \& Omland, K. (2004). Model selection in ecology and evolution. Trends in Ecology and Evolution, 19(2)

Johnson Gaither, C., Poudyal, N. C., Goodrick, S., Bowker, J. M., Malone, S., \& Gan, J. (2011). Wildland fire risk and social vulnerability in the Southeastern Unite States: An exploratory spatial data analysis approach. Forest Policy and Economics, 13, 24-36.

Jolliffe, I. (2002). Principal component analysis (2nd ed.). NY: Springer., 518 pp.

Katzman, R., Beccaria, L., Filgueira, F., Golbert, L., \& Kessler, G. (1999) Vulnerabilidad, activos y exclusión social en Argentina y Uruguay (Vulnerability, assets and social exclusion in Argentina and Uruguay). Documento de Trabajo 107. OIT. Santiago de Chile. http://intranet.oit.org.pe/index.php? option=com_content\&task=view\&id=507\&Itemid=1154. ISBN: 922311840 9; ISSN: 10203974 (in Spanish).

Keeley, J. E. (2005). Fire history of San Francisco East Bay region and implications for landscape patterns. International Journal of Wildland Fire, 14, 285-296.

Keeley, J. E., Fotheringham, C. J., \& Morais, M. (1999). Reexamining fire suppression impacts on shrubland fire regimes. Science, 284, 1829-1832.

Kitzberger, T. (2002). ENSO as a forewarning tool of regional fire occurrence in northern Patagonia, Argentina. International Journal of Wildland Fire, 11, 33-39.

Kitzberger, T., \& Veblen, T. T. (2003). Influence of climate on Fire in Northern Patagonia, Argentina. In T. T. Veblen, W. L. Baker, G. Montenegro, \& T. W. Swetnam (Eds.), Fire and climatic change in temperate ecosystems of the Western Americas (pp. 2296-2321). New York: Springer-Verlag.

Kitzberger, T., Veblen, T. T., \& Villalba, R. (1997). Climatic influences on fire regimes along a rain forest-to-xeric woodland gradient in northern Patagonia, Argentina. Journal of Biogeography, 24, 35-47.

Koenker, R. (2011). quantreg: Quantile regression. $R$ package version 4.76 . http://CRAN.Rproject.org/package=quantreg

Leone, V., Lovreglio, R., \& Martinez-Fernandez, J. (2002). Forest fires and anthropogenic influences: A study case (Gargano National Park, Italy). In X. Viegas (Ed.), Forest fire research $\mathcal{E}^{\sigma}$ wild-land fire safety (pp. 11-28). Rotterdam: Millpress.

Macie, E. A., \& Hermansen, L. A. (2002). Human influences on forest ecosystems: The Southern wild-land-urban interface assessment. Asheville, NC: US Department of Agriculture Forest Service, Southern Research Station General Technical Report SRS-55., 160 pp. http://www.srs.fs.usda.gov/pubs/gtr/gtr_srs055.pdf

Martell, D. L., Otukol, S., \& Stocks, B. J. (1987). A logistic model for predicting daily people-cause forest fire occurrence in Ontario. Canadian Journal of Fores Research, 17, 394-401.

Martinez, J., Chuvieco, E., \& Martín, P. (2000). Estimación de factores de riesgo humano de ignición en España mediante regresión logística (Estimation of factors of human risk of ignition in Spain, through logistic regression). USDA Forest Service Gen. Tech. Rep. PSW-GTR-208. http://www.fs.fed.us/psw/ publications/documents/psw_gtr208es/psw_gtr208es_281-294_martinez.pdf (in Spanish).

Martinez, J., Vega García, C., \& Chuvieco, E. (2009). Human-caused wildfire risk rating for prevention planning in Spain. Journal of Environmental Management, 90 , $1241-1252$.

Matossian, B. (2010). Expansión urbana y migración. El caso de los migrantes chilenos en San Carlos de Bariloche como actores destacados en la conformación de barrios populares (Urban growth and migration. Chilean migrants in San Carlos de Bariloche as actors in low class neighborhoods shaping). Scripta Nova. Revista Electrónica de Geografía y Ciencias Sociales. [online]. Barcelona: Universidad de Barcelona, Vol. XIV, no. 331 (76). http://www.ub.es/geocrit/sn/sn-331/sn-331-76.htm (in Spanish).

Mercer, D. E., \& Prestemon, J. P. (2005). Comparing production function models for wildfire risk analysis in the wildland-urban interface. Forest Policy and Economics, 7, 782-795.

Mermoz, M., Kitberger, T., \& Veblen, T. T. (2005). Landscape influences on occurrence and spread of wildfires in Patagonian forests and shrublands. Ecology, 86, 2705-2715.

Mermoz, M., Ubeda, C., Grigera, D., Brion, C., Martín, C., Bianchi, E., et al. (2009) (Nahuel Huapi National Park. Their ecological characteristics and conservation status) El Parque Nacional Nahuel Huapi. Sus características ecológicas y estado de conservación. Bariloche, Argentina: Editorial APN, PNNH., 80 pp. (in Spanish) 
Naumann, C. M., \& Sacholuz, L. A. (2000). Mapa de la vegetación del ejido de la ciudad de San Carlos de Bariloche (Vegetation map of San Carlos de Bariloche's municipal district). Revista de Geología Aplicada a la Ingeniería y al Ambiente, 14 92-97 (in Spanish)

Padilla, M., \& Vega Garcia, C. (2011). On the comparative importance of fire danger rating indices and their integration with spatial and temporal variables for predicting daily human-caused fire occurrence in Spain. International Journal of Wildfire, 20, 46-58.

Paradis, E., Claude, J., \& Strimmer, K. (2004). APE: Analyses of phylogenetics and evolution in R language. Bioinformatics, 20, 289-290.

PNMF. (2011). Forest fires statistics in Argentina. www.ambiente.gov.ar. Last access date: September 2011 (in Spanish).

Porrero Rodríguez, M. A. (2001). (Forest Fires. Investigation of causes) Incendios Forestales. Investigación de causas. Madrid: Mundi Prensa., 158 pp. (in Spanish)

Prestemon, J., \& Butry, D. (2005). Time to burn. Modeling wildland arson as an autorregresive crime function. American Journal of Agricultural Economics, 87(3), 756-770.

Prestemon, J., Butry, D., Abt, K., \& Sutphen, R. (2010). Net benefits of wildfire prevention education efforts. Forest Science, 56(2), 181-192.

Rangel, T. F., Felizola Diniz-Filho, J. A., \& Bini, L. M. (2006). Towards an integrated computational tool for spatial analysis in macroecology and biogeography. Global Ecology and Biogeography, 15, 321-327.

Richards, S. (2005). Testing ecological theory using the Information-Theoretic approach: Examples and cautionary results. Ecology, 86(10), 2805-2814.

Roman-Cuesta, R. M., Garcia, M., \& Retana, J. (2003). Environmental and human factors influencing fire trends in Enso and Non-Enso years in Tropical Mexico. Ecological Applications, 13(4), 1177-1192.
SPLIF. (2001-2005). Registros de incendios forestales, provincia de Río Negro (Forest fires records, Río Negro Province). Unpublished data (in Spanish).

Sturtevand, B. R., \& Cleland, D. T. (2007). Human and biophysical factors influencing modern fire disturbance in northern Wisconsin. International Journal of Wildland Fire, 16, 398-413.

Syphard, A. D., Radeloff, V. C., Keeley, J. E., Hawbaker, T. J., Clayton, M. K., Stewart, S. I., et al. (2007). Human influence on California fire regimes. Ecological Applications, $17(5), 1388-1402$.

Syphard, A. D., Radeloff, V. C., Hawbaker, T. J., \& Stewart, S. I. (2009). Conservation threats due to human-caused increases in fire frequency in mediterraneanclimate ecosystems. Conservation Biology, 23(3), 758-769.

Veblen, T., Kitzberger, T., \& Donnegan, J. (2000). Climatic and human influences on fire regimes in ponderosa pine forests in the colorado front range. Ecological Applications, 10, 1178-1195.

Veblen, T., Kitzberger, T., Raffaele, E., \& Lorenz, D. C. (2003). Fire history and vegetation changes in northern Patagonia, Argentina. In T. T. Veblen, W. L. Baker, G. Montenegro, \& T. W. Swetnam (Eds.), Fire and climatic change in temperate ecosystems of the Western Americas (pp. 265-295). New York: Springer-Verlag.

Vega García, C., Woodard, P. M., Titus, S. J., Adamowicz, W. L., \& Lee, B. S. (1995). A logit model for predicting the daily occurrence of human caused forest fires. Int. J. Wildland Fire, 5(2), 101-111.

Vilar de Hoyo, L., Gómez Nieto, I., Martín Isabel, M. P., \& Martínez Vega, F. J. (1997). Análisis comparativo de diferentes métodos para la obtención de modelos de riesgo humano de incendios forestales. 4ta Conferencia internacional sobre incendios forestales. Sevilla, Expaña. www.fire.uni-freiburg.de/sevilla-2007/contributions 